\title{
Rethinking Regional Development Strategies in Saudi Arabia: Planning Processes, Governance, and Implementation
}

\author{
Anas M. Almughairy ${ }^{1}$ \\ ${ }^{1}$ Urban Planning Department, College of Architecture and Planning, King Saud University, Saudi Arabia \\ Correspondence: Anas M. Almughairy, Urban Planning Department, King Saud University, P.O. Box 57448, \\ Riyadh 11574, Saudi Arabia. Tel: 966-1-1469-6524. E-mail: aalmughairy@ksu.edu.sa
}

Received: October 18, 2018

Accepted: April 23, 2019 Online Published: May 30, 2019

doi:10.5539/jsd.v12n3p131

URL: https://doi.org/10.5539/jsd.v12n3p131

\begin{abstract}
The Saudi government has engaged in regional planning to develop its 13 regions, reduce disparities between cities and rural areas, and balance resource distribution. In this paper I explore obstacles to regional development in Saudi Arabia and analyze outcomes in light of principles in the literature. I first identify seminal concepts of regional planning processes, governance, and implementation. These concepts are then organized into an evaluative framework for two case studies: Riyadh, the capital region of Saudi Arabia, and Makkah, the country's most populated region. Finally, I present results, draw conclusions from the two cases, and discuss implications for the future of Saudi regional development.
\end{abstract}

Keywords: National Spatial Strategy, NSS, regional development, regional governance, Saudi Arabia

\section{Introduction}

In the past three decades, the Saudi government has undertaken numerous regional planning tasks to develop its 13 regions, reduce disparities between cities and rural areas, and distribute resources for more balanced development (Ministry of Municipal and Rural Affairs [MoMRA], 2001). Regional planning tasks have been administered by MoMRA, which supervises city planning and municipal services country-wide through regional and urban centers. As with many other international regional planning exercises, the Saudi vision has not been free of the planning difficulties and contentious politics that frequently impede successful implementation. The conflicting socioeconomic and environmental objectives of regional planning and its promise to address an interplay of regional interests further complicate the process and make outcomes uncertain (Allmendinger \& Tewdwr-Jones, 2000; Haughton \& Counsell, 2004).

In this paper I shed light on regional development in Saudi Arabia through a pioneering project of tracing regional planning practices and analyzing outcomes in relation to planning and development principles in the literature. To start, I identify key factors and seminal concepts in regional planning, governance, and implementation. I arrange the factors in each of these three dimensions in an evaluative framework that I apply to two regional development case studies: Riyadh, the capital region, and Makkah, Saudi Arabia's most populous area. I then discuss the results, drawing conclusions from the two cases and presenting some policy implications for the future of regional development in the country.

\subsection{Evolution of Regional Planning and Economic Development Strategies}

More than any other discipline, regional planning has been deeply impacted by global economic fluctuations and the move from an industrial economy to a knowledge economy characterized by innovation and digital revolutions (Kemeny \& Storper, 2015). Theories and practices in the field have developed by two groups of scholars: planning and economic geography. Planning scholars focus on regional planning processes, governance, the socio-spatial distribution of people and employment, development gaps, the redefinition of urban-rural relationships, and comparative analysis of regional planning practices (Albrechts, Healey, \& Kunzmann, 2003; Allmendinger \& Haughton, 2010; Cabanillas, Aliseda, Gallego, \& Jeong, 2013; Galland, 2012; MacLeod, 2001; Parr, 1999). Economic geographers concentrate on regional production factors and their connection to the global market, economic growth and global competitiveness, regional specialization and clustering, and innovation in the dynamics of regional development (Amin, 1999; Barca, McCann, \& Rodríguez - Pose, 2012; Mackinnon, Cumbers, \& Chapman, 2002; Malecki, 2004; Stimson, Stough, \& Roberts, 2006; Storper, 2011). Although the 
two groups of scholars discuss similar regional development problems, they adopt distinctive approaches in analyzing regional policies and planning that represent important socioeconomic, institutional, and spatial perspectives.

Friedmann (1963) defined regional planning as practices aimed at reducing socioeconomic disparities between communities and boosting economic growth and prosperity. His definition was an attempt to make regional planning and policy a field of study and practice in which planners spatially intervene to shape civic and industrial development and provide regions with appropriate infrastructure and services (Friedmann, 1963). Following these principles, many countries around the world embraced regional planning and started to organize economic activities, define growth centers, and allocate resources and investment toward those centers; this practice was termed growth pole strategy (Parr, 1999). Despite enthusiasm for growth pole strategy in the 1960s and 1970s, the idea has been criticized as not being able to capture the nonspatial dynamics of regional economic development (Parr, 1999). It does not explain how urban centers foster innovation; incubate investors, entrepreneurs, and skilled workers; or track movement around the region. Furthermore, it provides no clear understanding of the functions of urban centers, networking policy, or sectoral policy, or how these factors integrate with economic activities (Christofakis \& Papadaskalopoulos, 2011). And, although Friedmann's definition captured the spatial and socioeconomic objectives of regional planning practice, Galland (2012) questioned how to make the location and quality of economic activities meet societal objectives.

Regional planning practices were deeply affected by the economic booms and busts of the 1980s and 1990s. Planners tended to concentrate economic activities in metropolitan regions by investing more in large cities, supporting agglomeration of related businesses, growing knowledge sharing between these businesses, and achieving spillover of economic opportunities to adjacent communities (Davoudi, 2009). Obviously, with globalization, metropolitan regions compete for movable knowledge-based industries; they must construct infrastructure, improve services, and raise liveability standards to attract skilled immigrants to the region (Malecki, 2004). The shift from developing hard infrastructure such as land, labor, and capital to improving connectivity between firms and sharing knowledge, technologies, and institutional capacity marks a new paradigm in 21st-century regional development (Malecki, 2004; Stimson et al., 2006).

\subsection{Regional Planning and Development in Saudi Arabia}

In Saudi Arabia, planning practice dates to the mid-1960s, when the Deputyship of Municipal Affairs at the Ministry of Interior (MoI) started to make master plans for the country's three major cities: Riyadh, Jeddah, and Makkah (MoMRA, 2015). At that time, capacity to perform planning was weak due to a lack of planning education and professional planners, so the government commissioned international planning firms to develop master plans and build planning practice by training Saudis on producing city plans. In 1975, responsibility for planning and municipal affairs was moved from the MoI to the newly established MoMRA. MoMRA was tasked with providing municipal services and planning for urban and regional development through a three-tiered system comprised of national, regional, and local levels. Regional planning practices began in earnest in the early 1980s, when the deputy of city planning assigned regional strategy-making to a team of planning experts and economists from the United Nations Development Program. The team combined senior international experts with freshly graduated Saudi architects and engineers to build the graduates' knowledge and skills in planning.

The National Spatial Strategy (NSS) was among the first planning projects to identify spatial development characteristics of the 13 Saudi regions. In 1986, the first draft of the NSS was presented to MoMRA and the Ministry of Economy and Planning (MEP) to be aligned with the latter's five-year development plan (Ramady, 2010). MoMRA and MEP collaborated to align their spatial and sectoral development policy but were not able to reach agreement until 2001, when the NSS, described as an umbrella of regional policy making in Saudi Arabia, was approved by the Council of Ministers (MoMRA, 2001). During that interim, regional municipalities, called Amanahs, made regional plans independently, and MoMRA itself assisted some remote Amanahs that lacked planning capacity. These plans were mainly based on instrumental planning practices by professionals who gathered data from across the region and drew regional development scenarios in the form of urban growth centers arranged hierarchically and connected by transportation corridors.

\subsection{Evaluative Framework}

With this understanding of how regional development strategies have evolved globally and within Saudi Arabia, I now focus on the evaluative framework. I based this framework on the literature and on policy reports developed by scholars, practitioners, and regional development agencies, looking at significant factors under three major themes: planning processes, governance, and implementation. In the following paragraphs, I explain fundamental concepts around the three themes and how they relate to one another and influence regional 
development strategies.

\subsubsection{Planning Processes}

The first theme in the framework is planning processes. Regional planning has much more complexity than smaller-scale planning tasks such as city planning or community development. The complexity comes not only from differences of scale, however. Other factors that complicate regional policy-making processes include diversity of regional planning objectives, volume of socioeconomic analyses and how they relate to spatial dimensions, multiple interests and stakeholders, and the participatory approach as a key component of success for planning (Albrechts et al., 2003; Allmendinger \& Tewdwr-Jones, 2000; Haughton \& Counsell, 2004). Regional policy making is a transformative practice that aims not only to solve development problems but also to create pragmatic plans to change values, processes, actions, and relationships between important actors in targeted regions (Albrechts, 2010). The overarching goal is to shape the economic development of a region by changing the dynamic of the socioeconomic relationships between people and places while preserving environmental assets and improving institutional capacity (Barca et al., 2012). Context-specific objectives cannot be decided by planners unilaterally; they must consult with regional stakeholders to understand their motives, interests, and vision for the region (Albrechts, 2010). Furthermore, planners need to educate stakeholders about regional development objectives and present global success stories of economically thriving regions and industry hubs (Albrechts et al., 2003).

After defining regional objectives, planners collaborate with regional economists and policy analysts in an evidence-based analysis of socioeconomic and sectoral data gathered from multiple public and private sources (Bachtler \& Yuill, 2001). Together, they use scientific methods, quantitative and qualitative, to understand the data and compare them with principles of regional economic modeling and spatial development. For instance, a planning team might classify economic activities in the region and consider the benefits of agglomerating related businesses (Mackinnon et al., 2002) or study how to enhance the idea of a learning region, where firms and individuals develop tacit knowledge around a specialized industry. Certainly, the team investigates the benefits of spatial concentration of economic activities and the effect of close geographic distances to support the making of the learning region (Mackinnon et al., 2002). To foster innovation and learning regions, the European Union demands its country members analyze regional innovation by identifying important socioeconomic, political, and institutional attributes that influence development and motivate stakeholders to coordinate path-dependent economic plans (Baier, Kroll, \& Zenker, 2013). Regions define their economies of scale through consistent acquisition of knowledge, skills, and expertise while their scope can be enhanced through agglomeration of firms in specific industries to enable continuous learning and spillover of expertise and activities into small towns (Coe, Hess, Yeung, Dicken, \& Henderson, 2004; Kemeny \& Storper, 2015). The study of economies of scale and scope, and their spatial manifestations, is an integral part of the regional planning process. After analyzing socioeconomic factors, spatial characteristics, and sectoral policies, the planning team can create development scenarios that reflect the facts, objectives, and institutional environment in which they will be implemented (Davoudi, 2009).

\subsubsection{Governance}

The second component of a regional development strategy is the governance system, which concerns context, institutional environment, and multilevel relationships among regional stakeholders. Indeed, assessing regional governance is critical to implementation of regional plans. The process starts with taking a broader view of governance and understanding relationships between development policies and actors at the national, regional, and local levels (Macleod, 2001). Regional governments need to organize and integrate planning in various departments (administration, services, infrastructure) while also engaging externally with the national government, businesses, and industries to discuss implementation (Bachtler \& Yuill, 2001). In a decentralized system, regions go beyond reliance on the nation-state to get their share of public investment. They have the authority to draw their development future, and design and implement plans aligned with national strategy (Macleod, 2001).

In most popular practices, regions create development authorities to integrate development policy across local jurisdictions in light of regional plans and national strategies (Albrechts et al., 2003). The development authority works to include strong firms and businesses who deliberate on development policies and voice their concerns about issues and the future of the regional market (Allmendinger \& Tewdwr-Jones, 2000). In dysfunctional regional authorities, localities can compete aggressively for resources and infrastructure projects, and resist any plan that limits their economic opportunities even if it serves regional growth as a whole (Waters \& Smith, 2002). To avoid aggressive competition between regional stakeholders, regions should institute participatory planning 
processes and a governance structure that supports regional policy implementation (Jessop, 2002; Pike, Rodríguez-Pose, \& Tomaney, 2007). Plans should clearly justify spatial selectivity of certain areas to direct investments and projects, and make them viable regional growth centers (Brenner, 2006; Galland, 2012).

\subsubsection{Implementation}

The final framework theme is implementation. Implementation of regional development strategy is cumbersome and demands long-term commitment from stakeholders. For outcomes to be realized, stakeholders require documents, reports, master plans, and programs that are easy to understand and implement (Cabanillas et al., 2013). Roles and responsibilities should be clearly defined and accompanied by implementation priorities and timetables for each organization involved (Bachtler \& Yuill, 2001; Davoudi, 2009). Planning practice is in danger of becoming congested if plans lack clarity or fragmented if people do not know who is doing what (Allmendinger \& Haughton, 2010). In addition, lack of capacity or tools to monitor changes and suggest alternative measures to deal with invariable internal and external difficulties can lead to implementation failure (Barca, 2009). Of note, regional strategy implementation goes much deeper than applying measures and meeting performance indicators set by the planning team. Rather, it entails cohesive social learning processes among stakeholders to meet regional growth objectives (Bryson, Crosby, \& Bryson, 2009; Davoudi, 2009; Hoernig \& Seasons, 2004). Planners and policy makers should test systems, educate stakeholders on successful implementation, and ensure power and policy compliance from government agencies, private sector organizations, and communities in the region (Lichfield, Kettle, \& Whitbread, 2016).

As I stated earlier, regional policy making is a transformative practice that demands well-designed planning processes supported by appropriate governance and institutional environments to ensure implementation and achieve objectives (see Figure 1). When planning for place-based regional development, planners should invest time studying the socioeconomic characteristics of the region (Organisation for Economic Co-operation and Development [OECD], 2009). In Regions Matter, the OECD (2009) advocated for regional strategies that reflect understanding of regional characteristics and are tailored to path-dependent economic development and growth. It also called for national government support through infrastructure subsidies, and businesses and innovation support systems, to enable regions to prosper and compete for global opportunities (OECD, 2009).

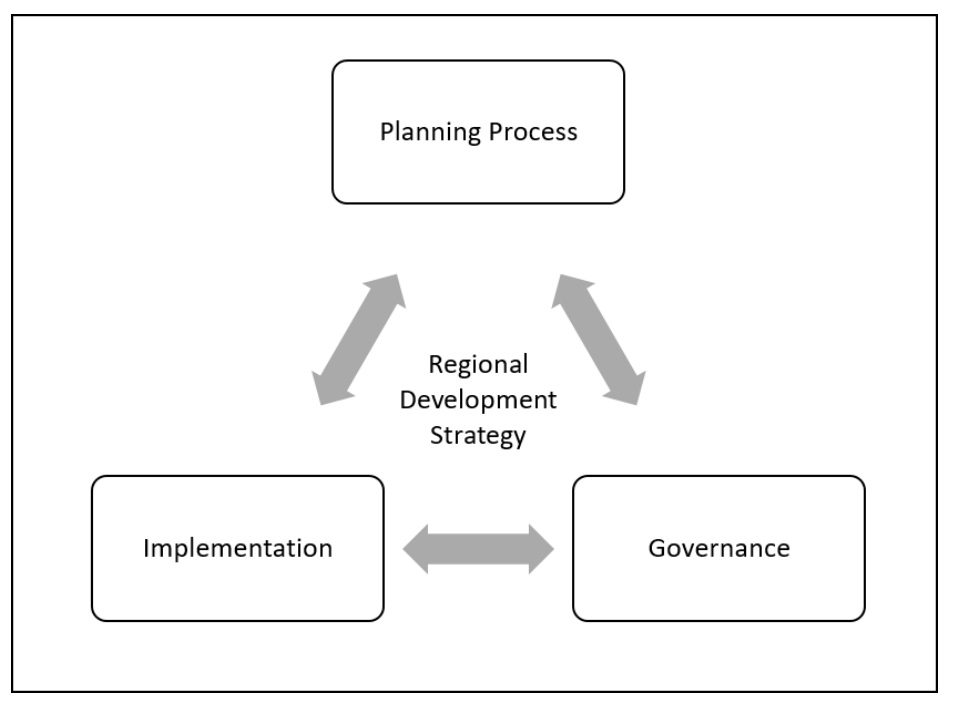

Figure 1. Successful regional development strategies rely on coordination of the planning process, governance, and implementation

\section{Method}

\subsection{Data Collection}

I investigated two distinct case studies of regional strategy-making in Saudi Arabia. In general, regional planning and development practices are rarely researched by planning scholars. Case study methodology gave me an in-depth understanding of the processes, behaviors, and factors that affected regional planning and outcomes (Yin, 2014) in the Riyadh and Makkah regions. I used comparative case study to analyze planning approaches and evaluate the institutional and governance structures that enabled or hindered the implementation of proposed regional strategies. 
I started my research by looking at the broader practices of spatial and sectoral planning in Saudi Arabia. I conducted multiple visits to MoMRA and MEP to gather valuable government reports on national and regional development strategies. MoMRA performs spatial planning at the national, regional, and local levels, whereas MEP designs sectoral development policy at the national level only. For that reason, my focus narrowed to look at regional planning undertaken by MoMRA and associated Amanahs. Studying the two regions of Riyadh and Makkah was intentional for two compelling reasons. First, they are the largest and most important regions in the country: Riyadh is the capital, and Makkah has the holiest site of the Islamic world (the Great Mosque of Mecca) Second, their development problems are distinct from each other and demand different planning approaches. The regional plans for Riyadh and Makkah were developed independently by Arriyadh Development Authority (ADA) and the Amanah of Makkah, respectively. Another important reason for choosing the two case studies stemmed from data availability and the accessibility of the main actors in the planning process, which enabled me to investigate selected evaluation criteria in the two regions.

I began my data collection in earnest by gathering government reports and regional strategy documents from MoMRA, ADA, and the Amanah of Makkah. I visited the three agencies, and met with the professional planners who had developed the regional strategies and supervised the private planning firm that conducted the spatial planning.

\subsection{Participant Characteristics}

I interviewed seven key informants to authenticate events and have them as points of contact to verify the accuracy of my research results:

- Interviewee 1, former deputy minister at MoMRA, at the interviewee's house, Riyadh, December 4, 2017.

- Interviewee 2, former director of urban planning at MoMRA, at the interviewee's house, Riyadh, December 9, 2017.

- Interviewee 3, consultant and advisor at MoMRA, at the interviewee's office, Riyadh, December 4, 2017.

- Interviewee 4, regional planning consultant at ADA, at the interviewee's office, Riyadh, November 22, 2017.

- Interviewee 5, former planning director for Riyadh Amanah, at my office, Riyadh, November 26, 2017.

- Interviewee 6, senior planner at Makkah Amanah, at the interviewee's office, Makkah, December 14, 2017.

- Interviewee 7, regional planning consultant at Makkah Governorate, at the interviewee's office, Makkah, December 15, 2017.

I manually transcribed the interviews for use in the research writing phase. Participation of key informants in qualitative inquiry provides insight from those directly involved in the case study under investigation, and their interview data can be used for triangulation and fact checking (Patton, 2015).

\subsection{Case Studies}

I turn now to a brief context description of the two case studies. The first case is Riyadh, the second-largest region in the country with a total area of $348360 \mathrm{~km}^{2}$ and 6.7 million inhabitants (ADA, 2012). Riyadh City, Saudi Arabia's capital, lies in the center of the region and has $76 \%$ of its population (ADA, 2012). ADA designed its regional development strategy to reduce regional disparities and balance development between urban growth centers. Further, the plan aims to increase the competitiveness of urban centers and direct government subsidies and infrastructure projects within five development zones (see Figure 2). 


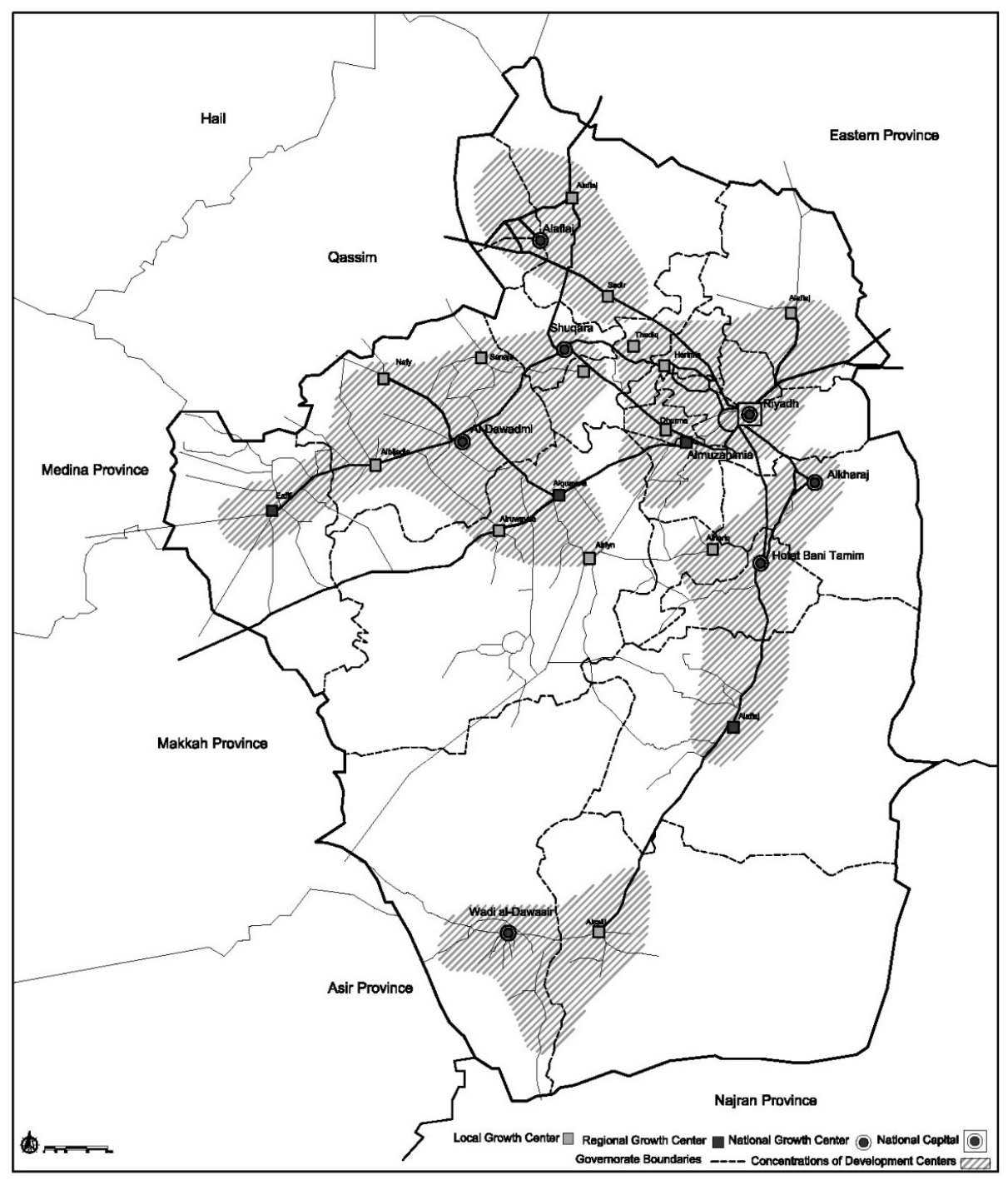

Figure 2. The Riyadh regional development strategy focuses on five development zones that include multiple regional and local growth centers (ADA, 2012)

The second case is Makkah, a region of strategic importance stemming from the existence of the Great Mosque of Mecca. It is the most populated region in the country, with around 6.9 million inhabitants, covering an area of $137000 \mathrm{~km}^{2}$. Unlike Riyadh region, in which most inhabitants are concentrated in Riyadh City, the population of Makkah is concentrated in three major cities: Jeddah, Makkah, and Taif. The regional development strategy for Makkah region was initiated in 2006 and updated and approved in 2012 (Makkah Amanah, 2012). It aims to reduce development disparities between urban centers and rural areas, and create diverse economic opportunities by harnessing the region's unique growth potential (see Figure 3). 


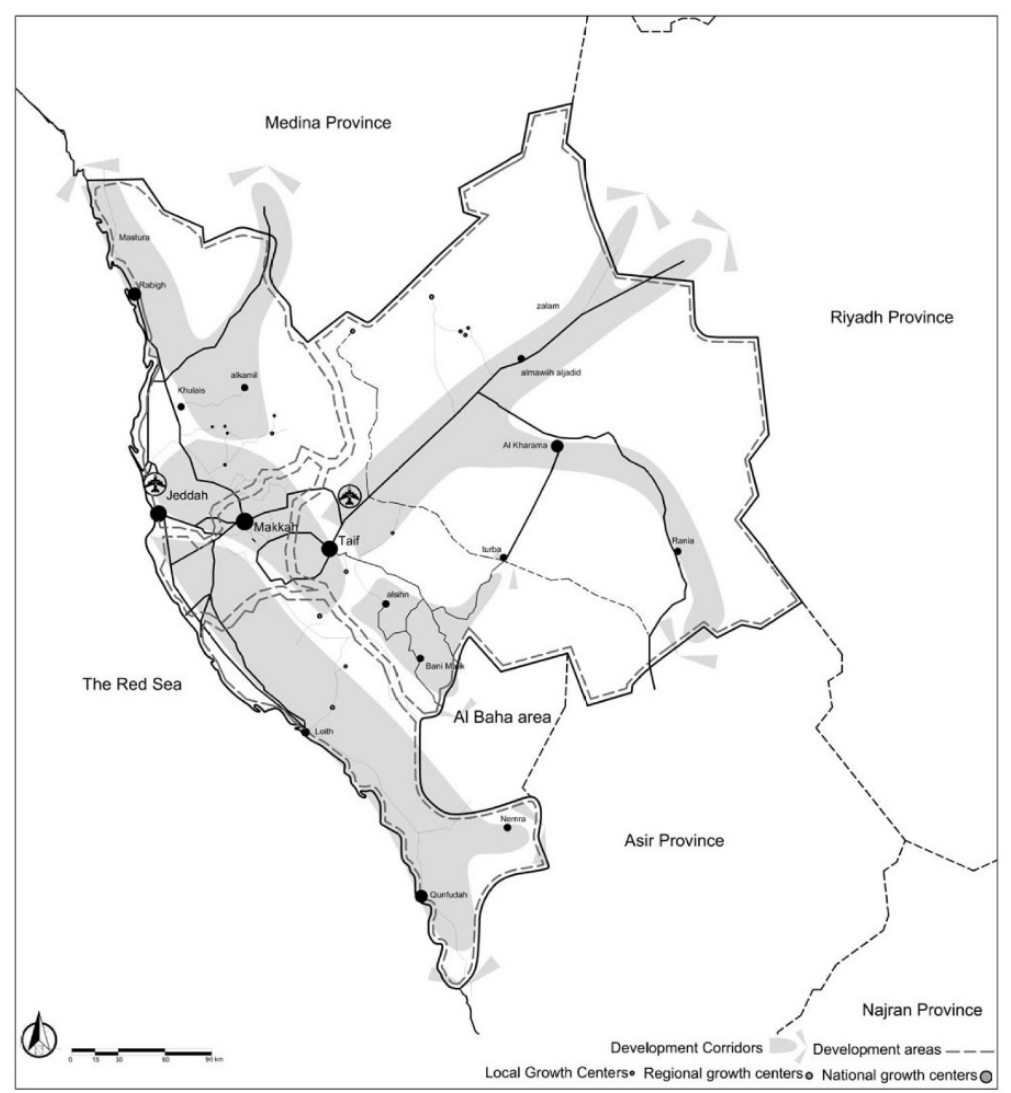

Figure 3. The Makkah regional development strategy aims to spread development outside the three large cities of Jeddah, Makkah, and Taif (Makkah Amanah, 2012)

\section{Results}

My comparative analysis of Riyadh's and Makkah's regional development strategies found significant variations in the evaluative framework variables of planning processes, governance, and implementation.

\subsection{Planning Processes}

Planning process results show that the case studies were similar in only two ways: both plans had well-defined regional development objectives and neither plan had a robust collection of evidence or socioeconomic analysis, despite a good understanding of spatial characteristics reflected in the spatial analysis (especially in the sections on development potential and limitations). On other criteria, Riyadh Amanah's regional development strategy was superior to that of Makkah's. First, the scope and scale of regional economic activities were reflected in the former but not the latter. As well, in terms of regional strategy-building, Riyadh's team adopted a participatory planning approach, involving multiple stakeholders through workshops and trips across the region. The Makkah Amanah planning team, however, took an instrumental rationality approach and relied on experts to understand facts and design regional strategies. Consequently, in Riyadh, interaction between the planning team and regional stakeholders enabled planners to establish strong connections between facts, plan objectives, and sectoral policies, and present them in the regional development strategies. Meanwhile, the Makkah regional planning team failed to establish clear connections between facts, plan objectives, and sectoral policies in its plan (see Table 1). 
Table 1. Comparative analysis of regional planning processes in Riyadh and Makkah regions

\begin{tabular}{lll}
\hline \multicolumn{1}{c}{ Evaluation criteria } & \multicolumn{1}{c}{ Riyadh region } & \multicolumn{1}{c}{ Makkah region } \\
\hline $\begin{array}{l}\text { Regional planning } \\
\text { objectives }\end{array}$ & $\begin{array}{l}\text { Well defined and focused on } \\
\text { development problems }\end{array}$ & $\begin{array}{l}\text { Well defined and focused on } \\
\text { development problems }\end{array}$ \\
\hline $\begin{array}{l}\text { Evidence collection and } \\
\text { socioeconomic analysis }\end{array}$ & $\begin{array}{l}\text { Evidence was collected but } \\
\text { socioeconomic analyses lacked } \\
\text { robustness }\end{array}$ & $\begin{array}{l}\text { Evidence was collected but } \\
\text { socioeconomic analyses lacked } \\
\text { robustness }\end{array}$ \\
\hline $\begin{array}{l}\text { Study of scale and scope of } \\
\text { regional economy }\end{array}$ & $\begin{array}{l}\text { Plans studied scope and scale of } \\
\text { economic activities }\end{array}$ & $\begin{array}{l}\text { Plans did not define scale or scope of } \\
\text { regional economy }\end{array}$ \\
\hline $\begin{array}{l}\text { Participatory planning } \\
\text { approach }\end{array}$ & $\begin{array}{l}\text { Multiple workshops involved regional } \\
\text { stakeholders (government departments } \\
\text { and business communities) }\end{array}$ & $\begin{array}{l}\text { The planning team worked mainly } \\
\text { in-house using an instrumental } \\
\text { rationality approach }\end{array}$ \\
\hline $\begin{array}{l}\text { Representation of facts and } \\
\text { objectives in regional } \\
\text { development scenarios }\end{array}$ & $\begin{array}{l}\text { Good agreement between facts and } \\
\text { objectives in development scenarios }\end{array}$ & $\begin{array}{l}\text { Poor agreement between facts and } \\
\text { objectives in development scenarios }\end{array}$ \\
\hline $\begin{array}{l}\text { Integration of sectoral } \\
\text { policies and spatial plans }\end{array}$ & $\begin{array}{l}\text { Well-established connection between } \\
\text { sectoral policies and spatial plans }\end{array}$ & $\begin{array}{l}\text { No clear connection between sectoral } \\
\text { policies and spatial plans }\end{array}$ \\
\hline
\end{tabular}

\subsection{Governance}

The second theme in the evaluation framework relates to regional governance and strategy-building. Results illustrate that Riyadh Amanah did better than Makkah Amanah in defining regional stakeholders but lacked clarity around relationships. Riyadh also dealt better with studying interactions between vertical and horizontal levels of regional governance, although this process was not clearly described in the project document (ADA, 2012). Both Amanahs adhered to centralized governance, where higher-level authority has the strongest voice in defining regional development. In Riyadh, MoMRA was able to reduce conflict by delegating authority to ADA to develop regional strategy, whereas in Makkah, a power struggle ensued between Makkah Amanah, Makkah Regional Authority, and Makkah Province. Finally, both plans were strongly integrated with the NSS, but localities still struggled to adjust local plans to the regional strategy (see Table 2).

Table 2. Comparative analysis of regional governance in Riyadh and Makkah

\begin{tabular}{|c|c|c|}
\hline Evaluation criteria & Riyadh region & Makkah region \\
\hline $\begin{array}{l}\text { Definition of regional } \\
\text { stakeholders and relationships } \\
\text { (institutional structure) }\end{array}$ & $\begin{array}{l}\text { Regional stakeholders were well } \\
\text { defined, but their relationships lacked } \\
\text { clarity }\end{array}$ & $\begin{array}{l}\text { Team did not sufficiently study } \\
\text { institutional or environmental } \\
\text { relationships beyond the municipal } \\
\text { sector }\end{array}$ \\
\hline $\begin{array}{l}\text { Multilevel (horizontal and } \\
\text { vertical) interactions explored } \\
\text { between regional actors }\end{array}$ & $\begin{array}{l}\text { Horizontal and vertical interaction } \\
\text { were studied as part of understanding } \\
\text { regional governance }\end{array}$ & $\begin{array}{l}\text { Horizontal and vertical interaction } \\
\text { were not studied as part of } \\
\text { understanding regional governance }\end{array}$ \\
\hline $\begin{array}{l}\text { Centralization and } \\
\text { decentralization of regional } \\
\text { governance system }\end{array}$ & $\begin{array}{l}\text { Central regional governance system } \\
\text { affected the flexibility and } \\
\text { implementation of the regional } \\
\text { development strategy }\end{array}$ & $\begin{array}{l}\text { Central regional governance system } \\
\text { affected the flexibility and } \\
\text { implementation of the regional } \\
\text { development strategy }\end{array}$ \\
\hline $\begin{array}{l}\text { Authority to carry out regional } \\
\text { planning }\end{array}$ & $\begin{array}{l}\text { MoMRA and Riyadh Amanah } \\
\text { delegated authority to ADA to carry } \\
\text { out regional planning }\end{array}$ & $\begin{array}{l}\text { Makkah Amanah, Makkah } \\
\text { Development Authority and Makkah } \\
\text { Governorate engaged in a regional } \\
\text { power struggle }\end{array}$ \\
\hline $\begin{array}{l}\text { Regional strategy integration } \\
\text { with national and local plans }\end{array}$ & $\begin{array}{l}\text { Strong integration between the NSS } \\
\text { and regional development strategy; } \\
\text { weak integration with local plans }\end{array}$ & $\begin{array}{l}\text { Strong integration between the NSS } \\
\text { and regional development strategy; } \\
\text { weak integration with local plans }\end{array}$ \\
\hline
\end{tabular}




\subsection{Implementation}

Results from the implementation analysis show that stakeholders in Riyadh were committed to implementing planning outcomes, but this was not the case in Makkah. The Riyadh planning team clarified outcomes (master plans, reports, and programs), whereas the Makkah team further complicated them. Both regional strategy teams needed to define regional actors' roles and responsibilities in plan implementation more clearly. Once again, Riyadh strategists were more successful in determining implementation programs, priorities, and timelines. Overall, the local and regional municipalities' capacities to implement regional strategies were not assessed, and neither implementation process was treated as a cohesive learning opportunity for stakeholders (see Table 3 ).

Table 3. Comparative analysis of implementation of regional development strategy in Riyadh and Makkah

\begin{tabular}{lll}
\hline \multicolumn{1}{c}{ Evaluation criteria } & \multicolumn{1}{c}{ Riyadh region } & \multicolumn{1}{c}{ Makkah region } \\
\hline $\begin{array}{l}\text { Stakeholders' commitment to } \\
\text { implementing planning outcomes }\end{array}$ & $\begin{array}{l}\text { Commitment to planning outcomes } \\
\text { was established through } \\
\text { participatory planning processes }\end{array}$ & $\begin{array}{l}\text { Commitment to planning outcomes } \\
\text { was not established properly }\end{array}$ \\
\hline $\begin{array}{l}\text { Level of understanding of planning } \\
\text { outcomes (master plans, reports, } \\
\text { and programs) }\end{array}$ & $\begin{array}{l}\text { Data and reports were well } \\
\text { represented but needed further } \\
\text { interpretation }\end{array}$ & $\begin{array}{l}\text { Data and reports were poorly } \\
\text { represented and in need of } \\
\text { significant improvements }\end{array}$ \\
\hline $\begin{array}{l}\text { Clarification of roles and } \\
\text { responsibilities for implementation }\end{array}$ & $\begin{array}{l}\text { Roles and responsibilities were not } \\
\text { defined clearly }\end{array}$ & $\begin{array}{l}\text { Roles and responsibilities were not } \\
\text { defined clearly }\end{array}$ \\
\hline $\begin{array}{l}\text { Implementation priority and } \\
\text { timeline }\end{array}$ & Well defined & Needed further details \\
\hline $\begin{array}{l}\text { Capacity of local and regional } \\
\text { stakeholders to adjust plans to } \\
\text { regional development strategy }\end{array}$ & Needed a more comprehensive & $\begin{array}{l}\text { Needed a more comprehensive } \\
\text { assessment }\end{array}$ \\
\hline $\begin{array}{l}\text { Implementation as a flexible and } \\
\text { cohesive learning process }\end{array}$ & Not established & Not established \\
\hline
\end{tabular}

\section{Discussion}

I discuss the research outcomes using the evaluative framework. As noted earlier, regional planning practice in Saudi Arabia dovetailed with the preparation of the NSS. The relationship between the two planning levels is deeper than it seems. For MoMRA officials, legitimacy of regional plans was based on NSS approval by the Council of Ministers. All interviewees except Interviewee 5 pointed out that this approval took almost 15 years to be granted (in 2001). Some agencies, such as MoI and the Ministry of Economy and Planning, have insisted on participating or being consulted in regional planning much like what happened with the NSS. The relationship between the planning levels will therefore likely continue to be a pivotal factor in Saudi regional development.

\subsection{Planning Processes}

Early regional planning endeavors were part of preparation of the NSS (Interviewee 1). Around 1984, the Deputyship of City Planning at MoMRA put together an in-house regional planning team to study spatial characteristics and population distribution of urban centers in Riyadh and Makkah (Interviewee 1). These initial planning efforts were humbling and effective learning practices but insufficient to produce sophisticated regional plans (Interviewee 2). After the approval of the NSS, MoMRA encouraged Riyadh and Makkah Amanahs to start a new and more sophisticated regional planning process using local teams and private planning firms as needed. From initiation until approval in 2012, regional plans were updated twice for each region. My analysis focused on the most recent practices, from 2009 (ADA, 2012; Makkah Amanah, 2012).

\subsubsection{Planning in Riyadh Region}

Regional plan development for Riyadh and Makkah took two distinct trajectories. For Riyadh, the process started with a clear mandate from MoMRA to ADA to develop regional strategy in alignment with the NSS structure and objectives. The planning team (local planners and international consultants) decided to execute this project based on collaboration and true engagement with regional stakeholders. They worked to identify stakeholders and invited them for roundtable discussions on the future of Riyadh region. The discussions culminated in initial 
objectives and observations about difficulties the team might face. One pitfall in defining regional planning objectives stemmed from the team's focus on problems rather than solutions, conflicting with the overarching goal of regional planning as a transformative practice that starts with a clear vision (Albrechts, 2010). My comparison of the objectives of the NSS and Riyadh's regional development strategy showed some similarities in terms of dealing with regional disparities and achieving balanced and sustainable development (ADA, 2012; MoMRA, 2001).

The Riyadh planning team next gathered relevant socioeconomic and environmental data from ministries and government agencies across the region. The earlier investment in building positive relationships with stakeholders in workshops helped with data collection (Interviewee 4). Even so, the team had trouble authenticating data, and missing data hindered robust analysis (Interviewees 4 and 5). For socioeconomic analysis specifically, the team could not measure the growth of economic sectors such as tourism, predict regional imports and exports, or conduct spatial analyses of productive industries and people migration for employment opportunities. Weaknesses in socioeconomic analysis did not prevent the team from recognizing problems such as increasing migration from smaller towns to larger centers, but the socio-spatial analysis was not indicative of real causes or future ramifications. Overall, the team did well in using available data and connected sectoral policies with spatial strategies; the regional development plans, reports, and programs supported the link established between sectoral and spatial policies (UN Habitat, 2016).

\subsubsection{Planning in Makkah Region}

In the second case study, Makkah Amanah used instrumental rationality in its regional planning process; the planning team made little to no effort to identify or engage important regional stakeholders (Interviewee 6). Planners made sure, when defining objectives, that they did not conflict with the NSS. Indeed, Makkah's regional development strategy final report dedicates the first 10 pages to explaining alignment with the NSS (Makkah Amanah, 2012). In the next phase, the team went to collect data from regional stakeholders, but most government organizations were uncomfortable with providing data (Interviewee 6). The decision not to engage regional stakeholders earlier in the planning process was a strategic mistake that cost the planning team an opportunity to build trust (Interviewee 7). Similar to the Riyadh case, the poor quality of the socioeconomic data affected the analysis and understanding of the region's socio-spatial dynamic. Officials acknowledged problems with the data collection and documentation and attributed them to a lack of organizational capacity and skilled employees (Interviewees 2 and 6). Overall, the final report, despite the good presentation and map drawing, was representative of problems with the regional planning process: There was a clear disconnect between sectoral policies and spatial plans.

\subsection{Governance}

As stated, regional planning involves multiple stakeholders and interests; therefore, establishing the link between planning and governance is critical to its success (Albrechts et al., 2003; Allmendinger \& Tewdwr-Jones, 2000). In Saudi Arabia, regional governance is more complex than other three-tiered systems because planning and governance are split between MoMRA and MoI. MoMRA is responsible for planning cities and providing municipal services; MoI is responsible for city and regional governance with a focus on public safety and security (see Figure 4). Coordination between the two ministries on the regional and local levels is part and parcel of regional governance. 


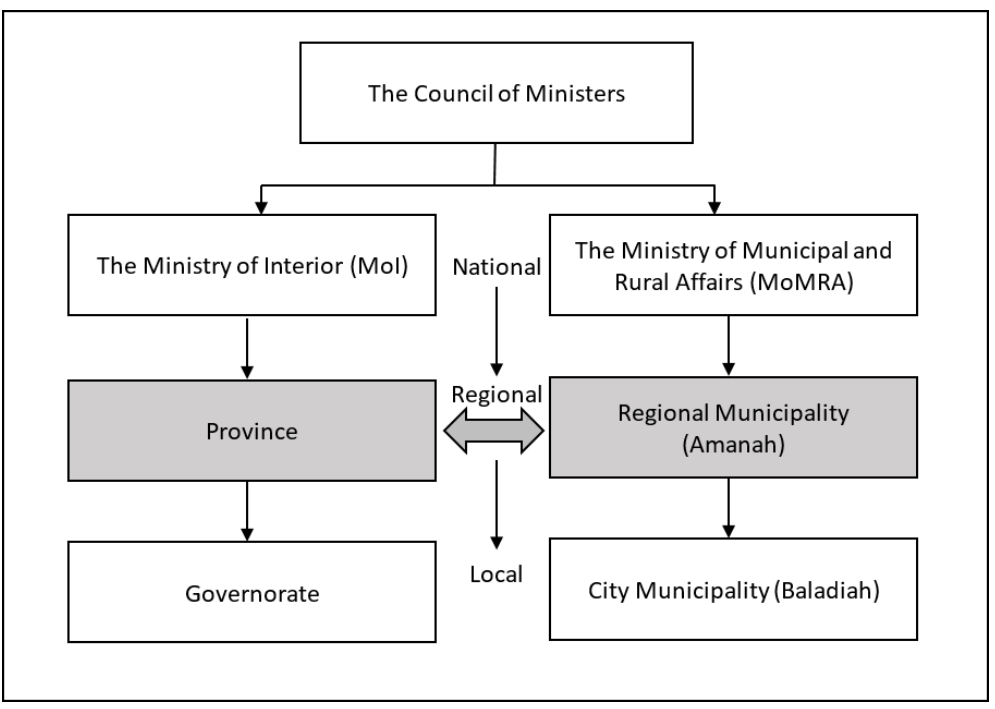

Figure 4. Understanding the complexity of regional governance is key to developing consensual regional strategy

\subsubsection{Governance in Riyadh Region}

For Riyadh's regional development strategy, the planning team was mindful of the complexity of regional governance. Even though ADA had a clear mandate from MoMRA to conduct regional planning, the team was careful not to alienate MoI or its affiliate organization, Riyadh Province. Indeed, despite affiliations between MoMRA and ADA in their planning missions, the ADA is chaired by the governor of Riyadh Province, which is affiliated with MoI. The ADA therefore worked as an appropriate platform for the regional planning process (Interviewees 3, 4, and 5), playing a significant role in facilitating vertical and horizontal interactions between government agencies. However, these efforts were not explained properly in the project documents (ADA, 2012). Research conducted by UN Habitat (2016) to assess regional governance in Saudi Arabia indicated that failure to realize multiscalar interactions between governments weakened regional planning, and Riyadh's regional planning effort did not coordinate multiscalar interactions between government departments in the implementation phases. Despite a strong connection between the regional plan and the NSS, there was no plan to coordinate or adjust local plans to meet regional development strategy objectives (Interviewee 5).

\subsubsection{Governance in Makkah Region}

In Makkah region, there was an obvious disconnect between regional and national efforts, which rose to the surface when planning got underway. The three regional organizations, Makkah Amanah (affiliated with MoMRA), Makkah Province (affiliated with MoI), and The Holy Makkah Development Authority, got into a contentious political debate about who should be doing what (Interviewee 7), and these politics overshadowed the policy-making process. Makkah Amanah was better equipped with planning staff and experience to execute the project (Interviewee 6), but under these circumstances, the planning team could not organize vertical or horizontal interactions between regional stakeholders and designed the regional development strategy unilaterally. Many stakeholders did not accept the outcomes, affecting plan implementation (Interviewee 6). For instance, the plan proposed building an airport at one regional growth center to encourage business and investment outside of the region's three main cities of Jeddah, Makkah, and Taif. The Civil Aviation Authority responded to Makkah Amanah's request and allocated resources to build the airport. However, according to an insider from Makkah Province (Interviewee 7), the project was shelved due to disagreements between government organizations.

Ultimately, the centralization of regional governance in Riyadh and Makkah impeded implementation. The effect was more pronounced in Makkah, whose regional plan lacked coordination between government agencies and flexibility with implementation assignments.

\subsection{Implementation}

Regional plan implementation cannot be separated from the planning process or governance. In many cases, success or failure in implementation can be attributed to mistakes that happened during planning or within the governance system (Stimson et al., 2006). 


\subsubsection{Implementation in Riyadh Region}

In Riyadh region, documents reflect that planners considered implementation and tried to be realistic about longand short-term implementation (ADA, 2012). The planning team increased stakeholder commitment and ownership of plan outcomes through effective engagement. ADA outlined roles and responsibilities for implementation, and continued to direct the regional plan until its final phases. The ADA team also did well with producing quality documents that included initiatives and programs with attached timelines. One program, for example, studied investment opportunities and regional competitiveness. However, when planning ended, ADA chose not to coordinate implementation and instead put it in the hands of the Riyadh Regional Council. The council seemed to be an appropriate choice, but it lacked the resources, experience, and human resources to implement multiple projects spread around the region (Interviewee 4). Given that implementation is still under discussion, the cohesive learning and adaptability of the plan have yet to be established; therefore, they were not subject to my assessment.

\subsubsection{Implementation in Makkah Region}

In Makkah region, the choice not to engage stakeholders in the planning process significantly reduced commitment to implementing the planning outcomes. I noted when visiting Makkah that many local municipalities were not aware of the regional development strategy project, and some of them did not understand their role in implementation. Obviously, despite volumes of regional strategy reports, the planning team failed to identify the roles and responsibilities of regional stakeholders or present documents that were easy for them to understand (Interviewee 7). Implementation priorities and timelines were not defined clearly and lacked important details such as programs, projects, costs, and who was going to pay the bill.

\section{Conclusions}

Regional development policy is attracting the attention of governments, planners, and policy makers around the world (OECD, 2009). They work together to shape the future of their regions and solve development problems caused by disparities and fragmentation (Storper, 2011). Regional planning processes, governance, and implementation play instrumental roles in changing socioeconomic dynamics and increasing competitiveness. My research shows that in Saudi Arabia, regional development strategy is deeply affected by these three factors. Regional planners and policy makers should seize the massive economic transformation opportunity that is happening in the country with programs and activities to diversify the Saudi economy and enhance quality of life. Thoughtful regional planning and governance could be useful transformation tools.

Certainly, before deciding on regional socio-spatial and economic policies in the shape of urban growth centers, corridors, or specialized economic zones, policy makers need to improve planning processes and governance to produce consensual development policies that regional stakeholders can implement. They need to better understand regional development issues such as migration from rural areas to cities, regional innovation systems, competitiveness of Saudi cities and regions, and resource and infrastructure distribution methods to support regional growth and the institutional capacity of regional municipalities.

The research outcomes present some planning and policy-making challenges that MoMRA, MoI, and other government agencies need to address in future regional development strategy endeavors. First, they need to improve collaborative planning capabilities and teams' ability to work across jurisdictional boundaries. Planning staff should be trained on facilitating and negotiating interests to avoid the gridlock that impedes regional policy implementation. Further, municipalities should build research centers and collaborate with universities to study socioeconomic and environmental issues in their regions. Improving the quality of regional data should be at the heart of research collaboration. Municipalities could also establish a forum to engage regional stakeholders in serious discussion about regional identity and the future of development.

As an implication of this study on regional planning practices in Saudi Arabia, and particularly the two regions that were the subject of the research, regional planning should take an effective turn to achieve development objectives. For each region, the discussion should start from this question: What is the vision of the region? Regions need to engage stakeholders in a preplanning assignment where they discuss their common challenges and economic growth. After that they can embark on the planning process, where concerted efforts should be made through the planning team to align the interests of national, regional, and local agencies and find common links and interdependancies between their program and sectoral policies in the region. Indeed, "alignment" is the magic word for regional planning, since regions have the authority to make plans, but national ministries own and allocate the budgets needed for regional projects and programs. Saudi regions need to draw on global examples of the successful creation of regional authorities responsible for planning and development or semigovernment bodies that enhance planning and collaboration across juridicational and instituational 
boundries. Finally, the main ingredients of a rigorous and collaborative planning process and effective governance will lead to the successful implementation of regional programs and policies that contribute to exploiting the unique potentials of each region and pave the way for a prosperous future.

\section{Acknowledgments}

I would like to thank my research participants, anonymous referees, and the Ministry of Municipal and Rural Affairs for supplying me with reports and documents.

\section{References}

Albrechts, L. (2010). More of the same is not enough! How could strategic spatial planning be instrumental in dealing with the challenges ahead? Environment and Planning B: Planning and Design, 37(6), 1115-1127. https://doi.org/10.1068\%2Fb36068

Albrechts, L., Healey, P., \& Kunzmann, K. R. (2003). Strategic spatial planning and regional governance in Europe. Journal of the American Planning Association, 69(2), 113-129. https://doi.org/10.1080/01944360308976301

Allmendinger, P., \& Haughton, G. (2010). Spatial planning, devolution, and new planning spaces. Environment and Planning C: Government and Policy, 28(5), 803-818. https://doi.org/10.1068\%2Fc09163

Allmendinger, P., \& Tewdwr-Jones, M. (2000). Spatial dimensions and institutional uncertainties of planning and the 'new regionalism.' Environment and Planning C: Government and Policy, 18(6), 711-726. https://doi.org/10.1068\%2Fc9953

Amin, A. (1999). An institutionalist perspective on regional economic development. International Journal of Urban and Regional Research, 23(2), 365-378. https://doi.org/10.1111/1468-2427.00201

Arriyadh Development Authority. (2012). Riyadh regional development strategy: Summary report. Riyadh, Saudi Arabia: Author.

Bachtler, J., \& Yuill, D. (2001). Policies and strategies for regional development: A shift in paradigm? Glasgow, Scotland: University of Strathclyde, European Policies Research Centre.

Baier, E., Kroll, H., \& Zenker, A. (2013). Templates of smart specialisation: Experiences of place-based regional development strategies in Germany and Austria. Karlsruhe, Germany: Fraunhofer ISI.

Barca, F. (2009). An agenda for a reformed cohesion policy: A place-based approach to meeting European Union challenges and expectations. Independent report prepared at the Request of the European Commissioner for Regional Policy, Danuta Hübner. Brussels, Belgium: European Commission.

Barca, F., McCann, P., \& Rodríguez - Pose, A. (2012). The case for regional development intervention: Place based versus place - neutral approaches. Journal of Regional Science, 52(1), 134-152. https://doi.org/10.1111/j.1467-9787.2011.00756.x

Brenner, N. (2006). New state spaces: Urban governance and the rescaling of statehood. Oxford, England: Oxford University Press.

Bryson, J. M., Crosby, B. C., \& Bryson, J. K. (2009). Understanding strategic planning and the formulation and implementation of strategic plans as a way of knowing: The contributions of actor-network theory. International Public Management Journal, 12(2), 172-207. https://doi.org/10.1080/10967490902873473

Cabanillas, F. J. J., Aliseda, J. M., Gallego, J. A. G., \& Jeong, J. S. (2013). Comparison of regional planning strategies: Countywide general plans in USA and territorial plans in Spain. Land Use Policy, 30(1), 758-773. https://doi.org/10.1016/j.landusepol.2012.06.001

Christofakis, M., \& Papadaskalopoulos, A. (2011). The growth poles strategy in regional planning: The recent experience of Greece. Theoretical and Empirical Researches in Urban Management, 6(2), 5-20. Retrieved from https://pdfs.semanticscholar.org/6f25/555912a89dd6582590a9e1ac0987055ad0ec.pdf

Coe, N. M., Hess, M., Yeung, H. W. C., Dicken, P., \& Henderson, J. (2004). 'Globalizing’ regional development: A global production networks perspective. Transactions of the Institute of British Geographers, 29(4), 468-484. https://doi.org/10.1111/j.0020-2754.2004.00142.x

Davoudi, S. (2009). Asymmetric development in spatial planning: Positivist content and post-modernist processes. In S. Davoudi, \& I. Strange (Eds.), Conceptions of space and place in strategic spatial planning (pp. 207-244). Abington, England: Routledge.

Friedmann, J. (1963). Regional planning as a field of study. Journal of the American Planning Association, 29, 
168-175. https://doi.org/10.1080/01944366308978061

Galland, D. (2012). Is regional planning dead or just coping? The transformation of a state sociospatial project into growth-oriented strategies. Environment and Planning C: Government and Policy, 30(3), 536-552. https://doi.org/10.1068\%2Fc11150

Haughton, G., \& Counsell, D. (2004). Regions and sustainable development: Regional planning matters. The Geographical Journal, 170(2), 135-145. https://doi.org/10.1111/j.0016-7398.2004.00115.x

Hoernig, H., \& Seasons, M. (2004). Monitoring of indicators in local and regional planning practice: Concepts and issues. Planning, Practice \& Research, 19(1), 81-99. https://doi.org/10.1080/0269745042000246595

Jessop, B. (2002). Liberalism, neoliberalism, and urban governance: A state theoretical perspective. Antipode, 34, 452-472. https://doi.org/10.1111/1467-8330.00250

Kemeny, T., \& Storper, M. (2015). Is specialization good for regional economic development? Regional Studies, 49(6), 1003-1018. https://doi.org/10.1080/00343404.2014.899691

Lichfield, N., Kettle, P., \& Whitbread, M. (2016). Evaluation in the planning process: The urban and regional planning series (Vol. 10). New York, NY: Pergamon Press.

MacKinnon, D., Cumbers, A., \& Chapman, K. (2002). Learning, innovation, and regional development: A critical appraisal of recent debates. Progress in Human Geography, 26(3), 293-311. https://doi.org/10.1191\%2F0309132502ph371ra

MacLeod, G. (2001). New regionalism reconsidered: Globalization and the remaking of political economic space. International Journal of Urban and Regional Research, 25(4), 804-829. https://doi.org/10.1111/1468-2427.00345

Makkah Amanah. (2012). Makkah regional development strategy: Comprehensive report. Makkah, Saudi Arabia: Ministry of Municipal and Rural Affairs.

Malecki, E. (2004). Jockeying for position: What it means and why it matters to regional development policy when places compete. Regional Studies, 38(9), 1101-1120. Retrieved from http://www.paca-online.org/cop/docs/Malecki_-_Competition_among_regions.pdf

MoMRA. (2001). National Spatial Strategy in Saudi Arabia: Executive report. Riyadh, Saudi Arabia: Author.

MoMRA. (2015). Planning evolution in Saudi Arabia. Riyadh, Saudi Arabia: Author.

Organisation for Economic Co-operation and Development. (2009). Regions matter: Economic recovery, innovation and sustainable growth. Paris, France: Author.

Parr, J. B. (1999). Growth-pole strategies in regional economic planning: A retrospective view: Part 2. $\begin{array}{llll}\text { Implementation and } & \text { outcome. Urban Studies, }\end{array}$ https://doi.org/10.1080\%2F0042098992971

Patton, M. Q. (2015). Qualitative research and evaluation methods: Integrating theory and practice. Thousand Oaks, CA: Sage.

Pike, A., Rodríguez-Pose, A., \& Tomaney, J. (2007). What kind of local and regional development and for whom? Regional Studies, 41(9), 1253-1269. https://doi.org/10.1080/00343400701543355

Ramady, M. (2010). The Saudi Arabian economy: Policies, achievements, and challenges. New York, NY: Springer.

Stimson, R. J., Stough, R. R., \& Roberts, B. H. (2006). Regional economic development: Analysis and planning strategy. New York, NY: Springer Science \& Business Media.

Storper, M. (2011). Why do regions develop and change? The challenge for geography and economics. Journal of Economic Geography, 11(2), 333-346. https://doi.org/10.1093/jeg/lbq033

UN Habitat. (2016). National Spatial Strategy of Saudi Arabia: Review and lessons. Nairobi, Kenya: Author.

Waters, R., \& Smith, H. L. (2002). Regional development agencies and local economic development: Scale and competitiveness in high-technology Oxfordshire and Cambridgeshire. European Planning Studies, 10(5), 633-649. https://doi.org/10.1080/09654310220145369

Yin, R. K. (2014). Case study research: Design and methods. Thousand Oaks, CA: Sage. 


\section{Copyrights}

Copyright for this article is retained by the author(s), with first publication rights granted to the journal.

This is an open-access article distributed under the terms and conditions of the Creative Commons Attribution license (http://creativecommons.org/licenses/by/4.0/). 